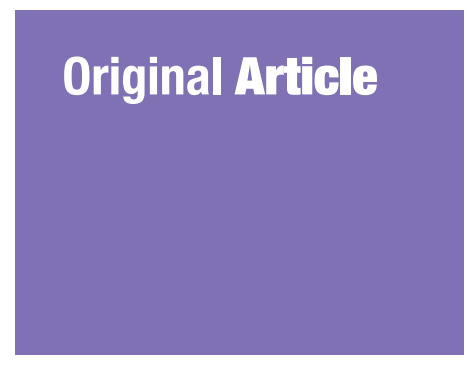

Submitted: 1 Apr 2016 Accepted: 22 Aug 2017 Online: 26 Oct 2017

\section{Balanced Fluid Versus Saline-Based Fluid in Post-operative Severe Traumatic Brain Injury Patients: Acid-Base and Electrolytes Assessment}

\author{
Mohamad Hasyizan HASSAN ${ }^{1,2}$, Wan Mohd Nazaruddin WAN \\ HASSAN $^{2}$, Rhendra Hardy Mohd Z AINI $^{2}$, Wan Fadzlina Wan Muhd \\ SHUKERI ${ }^{2}$, Huda ZAINAL ABIDIN ${ }^{2}$, ChONG Soon $\mathrm{Eu}^{2,3}$
}

Department of Neurosciences, School of Medical Sciences, Health Campus, Universiti Sains Malaysia, 16150 Kubang Kerian, Kelantan, Malaysia

2 Department of Anaesthesiology and Intensive Care, School of Medical Sciences, Universiti Sains Malaysia, 16150 Kubang Kerian, Kelantan, Malaysia

3 Regenerative Medicine Cluster, Advanced Medical and Dental Institute, Universiti Sains Malaysia, 13200 Bertam, Pulau Pinang, Malaysia

To cite this article: Hassan MH, Wan Hassan WMN, Zaini RHM, Shukeri WFWM, Zainal Abidin H, Chong SE. Balanced fluid versus saline-based fluid in post-operative severe traumatic brain injury patients: acid-base and electrolytes assessment. Malays J Med Sci. 2017;24(5):83-93. https://doi.org/10.21315/mjms2017.24.5.9

To link to this article: https://doi.org/10.21315/mjms2017.24.5.9

\title{
Abstract
}

Background: Normal saline (NS) is a common fluid of choice in neurosurgery and neurointensive care unit (ICU), but it does not contain other electrolytes and has the potential to cause hyperchloremic metabolic acidosis with prolonged infusion. These problems may be reduced with the availability of balanced fluid (BF), which becomes a more physiological isotonic solution with the presence of complete electrolyte content. This study aimed to compare the changes in electrolytes and acid-base between NS and BF (Sterofundin $\AA$ ISO) therapy for post-operative severe traumatic brain injury (TBI) patients in neuro-ICU.

Methods: Sixty-six severe TBI patients who required emergency craniotomy or craniectomy and were planned for post-operative ventilation were randomised into NS $(n=33)$ and BF therapy groups $(n=33)$. The calculation of maintenance fluid given was based on the Holliday-Segar method. The electrolytes and acid-base parameters were assessed at an $8 \mathrm{~h}$ interval for $24 \mathrm{~h}$. The data were analysed using repeated measures ANOVA.

Results: The NS group showed a significant lower base excess (-3.20 versus -1.35, $P=0.049)$, lower bicarbonate level (22.03 versus $23.48 \mathrm{mmol} / \mathrm{L}, P=0.031)$, and more hyperchloremia (115.12 versus $111.74 \mathrm{mmol} / \mathrm{L}, P<0.001)$ and hypokalemia (3.36 versus 3.70 mmol/L, $P<0.001)$ than the BF group at $24 \mathrm{~h}$ of therapy. The BF group showed a significantly higher level of calcium (1.97 versus $1.79 \mathrm{mmol} / \mathrm{L}, P=0.003)$ and magnesium (0.94 versus 0.80 mmol/L, $P<0.001)$ than the NS group at $24 \mathrm{~h}$ of fluid therapy. No significant differences were found in $\mathrm{pH}, \mathrm{pCO}_{2}$, lactate, and sodium level.

Conclusion: BF therapy showed better effects in maintaining higher electrolyte parameters and reducing the trend toward hyperchloremic metabolic acidosis than the NS therapy during prolonged fluid therapy for postoperative TBI patients.

Keywords: balanced solution, sodium chloride, severe traumatic brain injury, critical care, electrolytes, acidbase balance 


\section{Introduction}

In neurosurgery and intensive care, maintaining normovolemia and preventing the reduction of plasma osmolality is essential to prevent the development of cerebral edema. Normal saline (NS) is a common crystalloid used because of its iso-osmolarity. Plasma osmolarity should be properly maintained because its reduction results in edema in normal and abnormal brain (1). NS solution is preferable to lactated Ringer's (LR) solution because the latter is slightly hypoosmolar, thus worsening the cerebral edema. However, using NS is not without side effects. NS contributes to hyperchloremic metabolic acidosis $(2,3)$. The production of severe hyperchloremic acidosis by giving a large amount of unbalanced fluid may mask the diagnosis of perfusion deficit or result in inappropriate clinical intervention due to erroneous presumption of ongoing tissue hypoxia secondary to hypovolemia (4). In the study of intensive care unit (ICU) patients, base excess (BE) was shown to predict the outcome and to identify patients who have a high risk for mortality (5). Williams et al. (6) reported that, apart from developing metabolic acidosis, NS infusion can also significantly increase time to first urination. Among a group of patients undergoing abdominal aortic aneurysm repair who received either LR or NS in a doubleblind fashion (7), the NS treated patients developed hyperchloremic acidosis and required significantly more blood products than the RL group. Nevertheless, some authors emphasised that infusion-related hyperchloremic acidosis is benign (3), and that avoiding therapy-related hyperchloremic metabolic acidosis is always desirable when managing hypovolemic patients.

The total balanced concept of fluid is a new approach to resuscitation (8). Evidence shows that the balanced fluid (BF) concept offers an important effect of acid-base and electrolytes. When used in plasma-adapted volume replacement strategy [balanced crystalloid plus balanced hydroxyethyl starch (HES)] and given in high doses, this concept has better effects than the non-balanced strategy in terms of electrolyte concentration and BE (9). Moreover, balanced high molecular weight (MW) HES (Hestend $囚$ ) impairs the coagulation significantly less than the conventional high MW HES prepared in saline (hexastarch) (10). Saline-based HES may also alter the platelet function (11). Martin et al. (12) reported that HES prepared in NS (hexastarch) resulted in significantly more impaired thromboelastographic data than HES

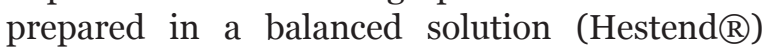
(8). A balanced colloidal volume replacement regime may also have other beneficial effects. In a prospective, randomised double-blind clinical trial for patients undergoing elective surgical procedure, the balanced HES formulation improved gastric mucosae perfusion more than the conventional HES (13). Therefore, alternative fluid solutions may be beneficial in prolonged neurosurgical procedures and neuro-intensive care settings, which involve significant blood loss and fluid, to maintain stable acid-base and electrolyte parameters without causing cerebral edema. We aimed to analyse the electrolyte and acid-base difference between NS and a balanced solution in post-operative severe traumatic brain injury (TBI) patients for a duration of $24 \mathrm{~h}$ in a neurocritical care setting.

\section{Material and Methods}

\section{Patients}

Following the approval by the ethics committee (USMKK/PPSP/JEPeM/2013 (21) and the written consent from the next of kin, 66 patients with severe TBI [Glasgow Coma Scale (GCS) 3 to $8 / 15$ post-initial resuscitation] who required emergency craniotomy or craniectomy and were admitted to neuro-intensive care and expected to be ventilated for more than $24 \mathrm{~h}$ were studied. We included patients with age of at least 16 years and consent given by next of kin, with American Society of Anesthesiologists (ASA) physical status I-II, who presented for emergency operation for TBI, with GCS preoperation, with post-resuscitation of less than 9, and with no major chest injury, intra-abdominal injury, or associated cervical spine injury. The exclusion criteria were patients with pre-existing acid-base and electrolyte disturbance $(\mathrm{pH}<$ 7.30), coagulopathy (INR $>1.8$, APTT $>60$ ), liver impairment (ALT/AST > 200, total bilirubin > 50), and renal impairment (creatinine clearance $<50$ ), as evidenced in the arterial blood gas, liver function test, and renal profile upon neuro-ICU admission, as well as patients with a history of allergy to the study solutions.

The sample size was determined on the basis of two mean formulas using Power \& Sample Size Calculations version 3.0.10 (Dupont and Plummer, 1997). The mean difference in post-infusion serum osmolarity between the $\mathrm{BF}$ regime and the saline-based group was 5 units [SD was estimated at 7.0; Waters et al. (7)], 
and the alpha is 0.05 with $80 \%$ power. Thus, the sample size including a 10\% dropout was 35 patients for each group.

All intraoperative fluid data were recorded. The total amount of fluid, type of fluid, and usage of blood and blood products were charted completely. Arterial blood gas and electrolytes were monitored at $1-2 \mathrm{~h}$ intervals according to the patients' condition. Acid-base and electrolyte levels were kept at normal levels, and intraoperative correction was performed as necessary. Baseline ABG and electrolyte were taken post-operatively, and any associated derangement of the acid-base and electrolytes profiles would exclude the patients from the study.

Post-operatively, the patients were randomised through block randomisation using eight ballots cards. Three different grouping sequences (BBB, SSS, BBS, SSB, BSB, SBS, BSS, and SBB) were made through the sealed envelope system by the neuro-ICU team leader in charge of receiving two different maintenance fluid regimes by double-blinded randomisation. Group B patients were given balanced crystalloid (Sterofundin $\AA$ ISO, B. Braun, Germany) only, and Group $\mathrm{S}$ patients were infused with salinebased crystalloid (NS 0.9\%, B. Braun, Germany) solutions only. In the neuro-ICU, standard monitoring (intra-arterial blood pressure, heart rate, ECG, and SPO2) was connected to the patients, and vital signs were assessed at 10 min intervals. The patients were sedated with IV propofol infusion (1-4 $\mathrm{mg} / \mathrm{kg}$ ) to achieve the RASS score of less than -2. The analgesic IV fentanyl or IV morphine was also administered. The maintenance fluid was started as soon as the patients reached the ICU. The patients were kept ventilated for $24 \mathrm{~h}$ at the spontaneous intermittent mandatory ventilation (SIMV) mode, and the volume control was set to a tidal volume of $8 \mathrm{~mL} / \mathrm{kg}$. The peak end expiratory pressure was adjusted according to the patients' $\mathrm{FiO} 2$ and partial pressure of oxygen $\left(\mathrm{PaO}_{2}\right)$ and carbon dioxide $(\mathrm{PaCO} 2)$. The respiratory rates were assessed according to the patients' $\mathrm{PaCO} 2$ level. The $\mathrm{FiO}_{2}$ was adjusted according to the patients' $\mathrm{PaO} 2$ level.

Regarding the maintenance fluid therapy, the crystalloid solutions were administered at approximately $10 \mathrm{~mL} / \mathrm{kg} /$ day for the first $10 \mathrm{~kg}$, followed by $5 \mathrm{~mL} / \mathrm{kg} /$ day for the subsequent $10 \mathrm{~kg}$ and $2 \mathrm{~mL} / \mathrm{kg} /$ day for the subsequent weights. The trigger for the fluid bolus was when the inferior vena cava size was less than 1.6 with variability of more than $13 \%$ or when the urine output was less than $0.5 \mathrm{~mL} / \mathrm{kg} / \mathrm{h}$. Intravenous infusion of noradrenaline was started when the patients' mean arterial pressure was less than $60 \mathrm{mmHg}$ after a fluid bolus of $30 \mathrm{~mL} / \mathrm{kg}$. Packed red blood cells would be transfused if the hemoglobin level was less than $9 \mathrm{~g} / \mathrm{dL}$ or if the hematocrit decreased to less than $21 \%$. The amount of total fluids given, blood, and blood products transfused was recorded. Any inotropic support and transfusion of blood and blood products in the neuro-ICU were charted and documented.

\section{Measurement}

The arterial blood samples were taken after the surgery as baseline at $8 \mathrm{~h}$ intervals until the $24 \mathrm{~h}$ neuro-ICU stay was completed. The renal function tests were taken at $8 \mathrm{~h}$ intervals in the neuro-ICU. The serum and urine osmolarity were taken at admission to ICU and at $24 \mathrm{~h}$ after ICU admission.

These samples were analysed for $\mathrm{pH}$, $\mathrm{PaCO} 2, \mathrm{HCO}_{3}^{-}$, standard base excess, concentrations of $\mathrm{Na}^{+}, \mathrm{K}^{+}$, and serum lactate, which were all integrated in the blood gas analyser (GEM Premier 3000, Instrumentation Laboratory, USA). The concentrations of serum $\mathrm{Cl}-, \mathrm{PO}_{4-}, \mathrm{Mg}^{2+}$ and albumin were measured using the same blood samples (COBAS Integra $\AA$ 800 System, Roche, USA). The methodology of the study was simplified in the algorithm flow chart of the methodology (Figure 1). 


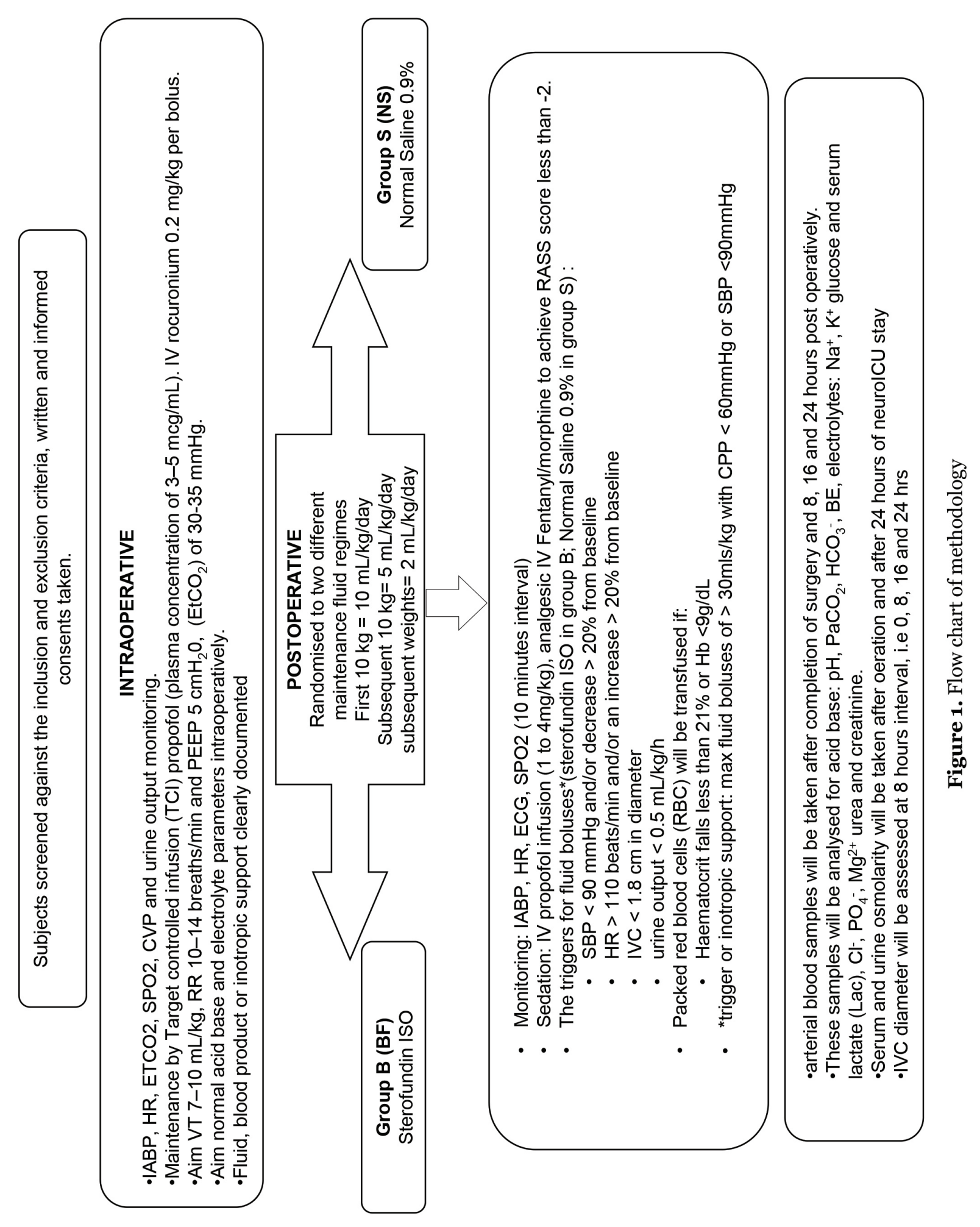




\section{Statistics}

Statistical analysis was conducted by using SPSS version 12.0. The demographic data in between groups were compared with the independent $t$-test/Mann-Whitney test or X2 test/Fisher exact test where appropriate. The intragroup and intergroup differences were analysed with repeated measures ANOVA where appropriate. The results were expressed as the mean and standard deviation or the frequency where appropriate. The level of significance was determined as $P<0.05$.

\section{Results}

We recruited 66 patients who underwent operation upon their admission to neuro-ICU. However, two patients were excluded from the study in the balanced solution group because they had severe coagulopathy and hemodynamic instability, as indicated in the demographic data, and they passed away before the study was completed (Table 1). The patients did not differ in age, sex, ASA classification, type of injury, type of operation, and duration of operation. However, as shown in Table 2, the GCS on arrival $(P=0.004)$ and the GCS pre-operation $(P=$ o.012) were significant.

As shown in Table 3, both treatment groups were compared regardless of time. According to the test of between-subjects effect, a significant difference $(P=0.040)$ of the mean $\mathrm{BE}$ concentration with a mean difference of 1.23 (0.06, 2.42) was found. The bicarbonate level was also significantly different $(P=0.019)$ between the two groups with a mean difference of $1.15(0.20,2.11)$ regardless of time.

Table 4 shows no significant difference in the mean serum sodium concentration between the two different groups based on time ( $F=1.26, P=0.293)$. Both treatment groups showed a gradual increase in serum sodium level over a $24 \mathrm{~h}$ period. However, both fluids resulted in a normal sodium level at the end of the study period, with a mean sodium level of 143.94 (141.06, $146.82 \mathrm{mmol} / \mathrm{L})$ and 142.93 $(139.97,145.90 \mathrm{mmol} / \mathrm{L})$ in the saline and the balanced group, respectively. A significant difference was found in the mean chloride concentration between the two groups based on time at 0,8 , and $24 \mathrm{~h}(F=8.61, P=0.001)$. The balanced solution showed a reduced chloride level over a $24 \mathrm{~h}$ period. However, at the end of the study period, both fluid therapies caused hyperchloremia, with a higher chloride concentration in the NS group: 115.12 (112.44, $117.79 \mathrm{mmol} / \mathrm{L})$ versus 111.74 (108.98, 114.50
mmol/L). A significant difference was found in the mean serum potassium between the two group based on time, particularly at $8 \mathrm{~h}$ and $24 \mathrm{~h}$ (F $=6.88, P<0.001)$. The infusion of the salinebased solution showed a reduction in serum potassium content, and it subsequently led to hypokalemia over a $24 \mathrm{~h}$ period: 3.36 (3.22, $3.50 \mathrm{mmol} / \mathrm{L})$. At $\mathrm{o} \mathrm{h}$ and $24 \mathrm{~h}$, a significant difference was found in the mean serum calcium between the two groups based on time $(F=5.26$, $P=0.003)$. The calcium content significantly decreased at the $24 \mathrm{~h}$ infusion of the saline-based solution, with a concentration of 1.79 (1.69, 1.89 $\mathrm{mmol} / \mathrm{L})$. A significant difference was observed in the mean serum magnesium between the two groups based on time at 0,16 , and $24 \mathrm{~h}(F$ $=10.36, P<0.001)$. Improvement of serum magnesium was observed after the $24 \mathrm{~h}$ infusion of the balanced solution. No hypomagnesemia was elicited after the $24 \mathrm{~h}$ infusion of both fluids.

Table 5 showed no significant difference in the mean serum $\mathrm{pH}$ concentration between the two groups based on time $(F=0.674, P=0.572)$. However, the balanced solution group exhibited a gradual increase in $\mathrm{pH}$ over time. By contrast, a significant difference was found in the mean arterial $\mathrm{pCO}_{2}$ level between the two different groups based on time at 0,8 , and $16 \mathrm{~h}(F=4.89$, $P=0.004)$. However, at $24 \mathrm{~h}$, the pCO2 levels in both treatment groups were in the normal limit. At $\mathrm{o}, 16$, and $24 \mathrm{~h}$, a significant difference was found in the $\mathrm{BE}$ concentration between the two groups based on time $(F=2.78, P=0.049)$; the patients in the saline group had a lower BE. The BE was slightly low at $24 \mathrm{~h}$ in the saline group at $-3.20(-4.26,-2.14)$ and normal in the balanced group at $-1.35(-2.43,-0.27)$. A significant difference was observed in the mean serum bicarbonate level between the two groups based on time at $16 \mathrm{~h}$ and $24 \mathrm{~h}(F=4.65, P=0.031)$; the bicarbonate level in the balanced solution group was slightly higher after a $24 \mathrm{~h}$ infusion at $23.48(22.66,24.28 \mathrm{mmol} / \mathrm{L})$. No significant difference was found in the mean serum lactate between the two different groups based on time $(F=0.67, P=0.571)$. Both fluid therapies resulted in an improved lactate level over time.

Based on the time-treatment interaction, the saline fluid group showed a steep increase in serum osmolarity from $287.84 \mathrm{mmol} / \mathrm{L}$ (281.22, 294.66) to $300.43 \mathrm{mmol} / \mathrm{L}$ (293.12, 307.13). The BF group showed a mild increment in serum osmolarity from $292.48 \mathrm{mmol} / \mathrm{L}$ (285.55, 307.73 ) to $294.58 \mathrm{mmol} / \mathrm{L}(286.04,301.12)$. No significant difference was found in the mean serum osmolarity between the two groups based on time $(F=14.54, P=0.055)$. 
Table 1. Demographics profile of categorical variables of severe traumatic brain injury patients

\begin{tabular}{|c|c|c|c|c|}
\hline Variables & $\begin{array}{c}\text { Saline group* } \\
(\%)\end{array}$ & $\begin{array}{c}\text { Balanced group** } \\
\text { (\%) }\end{array}$ & $X^{2}$ value (df) & $P$-value \\
\hline \multicolumn{5}{|l|}{ Sex } \\
\hline male & $30(90.9)$ & $25(83 \cdot 3)$ & $0.82(1)$ & $0.462^{\mathrm{a}}$ \\
\hline female & $3(9.1)$ & $5(16.7)$ & & \\
\hline \multicolumn{5}{|l|}{ ASA } \\
\hline $\mathrm{I}$ & $31(93.9)$ & $27(87.1)$ & $0.90(1)$ & $0.419^{\mathrm{a}}$ \\
\hline II & $2(6.1)$ & $4(12.9)$ & & \\
\hline \multicolumn{5}{|l|}{ Type of injury } \\
\hline EDH & $12(36.4)$ & $9(29.0)$ & $6.07(4)$ & $0.194^{\mathrm{a}}$ \\
\hline $\mathrm{SDH}$ & $6(18.2)$ & $5(16.1)$ & & \\
\hline SAH & $3(9.1)$ & o (o) & & \\
\hline Contussion & $4(12.1)$ & $2(6.5)$ & & \\
\hline Mixed & $8(24.2)$ & $15(48.4)$ & & \\
\hline \multicolumn{5}{|l|}{ Operation } \\
\hline Craniectomy & $15(45.5)$ & $15(48.4)$ & $4.90(3)$ & $0.179^{b}$ \\
\hline Craniotomy & $11(33 \cdot 3)$ & $7(22.6)$ & & \\
\hline EVD & $4(12.1)$ & $1(3.2)$ & & \\
\hline Craniectomy + EVD & $3(9.1)$ & $(25.8)$ & & \\
\hline
\end{tabular}

${ }^{*} n=33 \quad{ }^{* *} n=31 \quad$ a Fisher exact test $\quad{ }^{\mathrm{b}}$ pea

Table 2. Demographics profile of numerical variables of severe traumatic brain injury patients

\begin{tabular}{|c|c|c|c|c|}
\hline variables & $\begin{array}{l}\text { Saline group* } \\
\text { mean (SD) }\end{array}$ & $\begin{array}{c}\text { Balanced group }{ }^{* *} \\
\text { mean (SD) }\end{array}$ & t-statistic (SD) & $P$-value \\
\hline Age (years & $20(22)^{a}$ & $25(30)^{a}$ & $-1.51^{b}$ & $0.130^{c}$ \\
\hline GCS arrival & $8.64(2.58)$ & $6.71(2.63)$ & $2.95(62)$ & 0.004 \\
\hline GCS pre op & $8(2)^{\mathrm{a}}$ & $6(5)^{\mathrm{a}}$ & $-2.52^{b}$ & $0.012^{\mathrm{c}}$ \\
\hline $\begin{array}{l}\text { Duration of operation } \\
\text { (min) }\end{array}$ & 230.91(161.74) & $214.52(54.03)$ & $6.19(61)$ & 0.593 \\
\hline
\end{tabular}

${ }^{*} n=33 \quad{ }^{* *} n=31 \quad{ }^{\mathrm{a}}$ Median (IQR) $\quad{ }^{\mathrm{b}} \mathrm{Z}$ test $\quad{ }^{\mathrm{c}}$ Mann-Whitney test 
Original Article | Balanced fluid vs saline in traumatic brain injury

Table 3. Mean difference of electrolytes (mmol/L) and acid base parameters among saline vs. balance fluid group (treatment effect)

\begin{tabular}{|c|c|c|c|c|c|}
\hline parameters & $\begin{array}{l}\text { Saline group } \\
\text { Mean (SD) }\end{array}$ & $\begin{array}{l}\text { Balanced group } \\
\text { Mean (SD) }\end{array}$ & $\begin{array}{c}\text { Mean Difference } \\
(95 \% \mathrm{CI})\end{array}$ & $F$-stat (dF) & $P$-value \\
\hline \multicolumn{6}{|l|}{ Electrolytes } \\
\hline $\mathrm{Na}^{+}$ & $141.38(7.64)$ & $140.72(9.69)$ & $0.66(-3.17,4.99)$ & $0.12(1)$ & 0.731 \\
\hline $\mathrm{Cl}^{-}$ & $114.12(5.97)$ & $112.57(5.62)$ & $1.55(-1.35,4.44)$ & $1.13(1)$ & 0.290 \\
\hline+ & $3.71(0.29)$ & $3.71(0.30)$ & $0.004(-0.15,1.53)$ & $0.003(1)$ & 0.957 \\
\hline $\mathrm{Ca}^{2+}$ & $1.85(0.12)$ & $1.87(0.13)$ & $0.01(-0.05,0.08)$ & $0.321(1)$ & 0.573 \\
\hline $\mathrm{Mg}^{2+}$ & $0.79(0.13)$ & $0.81(0.13)$ & $0.02(-0.05,0.08)$ & $0.25(1)$ & 0.619 \\
\hline \multicolumn{6}{|l|}{ Acid base } \\
\hline $\mathrm{pH}$ & $7.36(0.04)$ & $7.38(0.04)$ & $0.013(-0.007,0.033)$ & 1.79 (1) & 0.186 \\
\hline $\mathrm{pCO}_{2}$ & $36.20(3.04)$ & $36.72(3.06)$ & $0.52(-1.00,2.04)$ & $0.46(1)$ & 0.501 \\
\hline BE- & $-3.70(2.35)$ & $-2.46(2.34)$ & $1.23(0.06,2.42)$ & $4 \cdot 38(1)$ & 0.040 \\
\hline $\mathrm{HCO}_{3-}^{-}$ & $21.28(1.91)$ & $22.43(1.91)$ & $1.15(0.20,2.11)$ & $5.83(1)$ & 0.019 \\
\hline lactate & $1.96(1.44)$ & $1.87(1.45)$ & $0.91(-0.63,0.81)$ & $0.064(1)$ & 0.801 \\
\hline
\end{tabular}

Repeated measure ANOVA between group analysis was applied.

Level of significance was set at 0.05 (two-tailed)

Table 4. Comparison of electrolytes level (mmol/L) between saline vs. balance fluid based on time (time-treatment interaction)

\begin{tabular}{|c|c|c|c|c|c|c|}
\hline Parameter & Type of fluid & $\begin{array}{l}\text { o hours } \\
\text { Mean } \\
(95 \% \mathrm{CI})\end{array}$ & $\begin{array}{c}8 \text { hours } \\
\text { Mean } \\
(95 \% \mathrm{CI})\end{array}$ & $\begin{array}{l}16 \text { hours } \\
\text { Mean } \\
(95 \% \mathrm{CI})\end{array}$ & $\begin{array}{l}24 \text { hours } \\
\text { Mean } \\
(95 \% \mathrm{CI})\end{array}$ & $P$-value (F) \\
\hline \multirow[t]{2}{*}{$\mathrm{Na}^{+}$} & Saline & $\begin{array}{c}138.82 \\
(136.88 \\
140.76)\end{array}$ & $\begin{array}{c}140.46 \\
(134.36 \\
146.55)\end{array}$ & $\begin{array}{c}142.30 \\
(139.57 \\
145.03)\end{array}$ & $\begin{array}{c}143.94 \\
(141.06, \\
146.82)\end{array}$ & $0.293(1.26)$ \\
\hline & Balanced & $\begin{array}{c}138.77 \\
(136.78, \\
140.77)\end{array}$ & $\begin{array}{c}138.29 \\
(132.80 \\
144.58)\end{array}$ & $\begin{array}{c}142.97 \\
(140.06 \\
145.68)\end{array}$ & $\begin{array}{c}142.93 \\
(139.97 \\
145.90)\end{array}$ & \\
\hline \multirow[t]{2}{*}{$\mathrm{Cl}^{-}$} & Saline & $\begin{array}{c}112.06 \\
(109.85 \\
114.27)\end{array}$ & $\begin{array}{c}110.49 \\
(108.27 \\
112.70)\end{array}$ & $\begin{array}{c}112.64 \\
(110.30 \\
114.97)\end{array}$ & $\begin{array}{c}115.12 \\
(112.44 \\
117.79)\end{array}$ & $\begin{array}{l}0.001 \\
(8.61)\end{array}$ \\
\hline & Balanced & $\begin{array}{c}118.67 \\
(116.40, \\
120.96)\end{array}$ & $\begin{array}{c}113.23 \\
(110.93 \\
115.51)\end{array}$ & $\begin{array}{c}112.83 \\
(110.44 \\
115.24)\end{array}$ & $\begin{array}{c}111.74 \\
(108.98 \\
114.50)\end{array}$ & \\
\hline \multirow[t]{2}{*}{$\mathrm{K}^{+}$} & Saline & $\begin{array}{c}3.84 \\
(3.66,4.02)\end{array}$ & $\begin{array}{c}4.03 \\
(3.83,4.24)\end{array}$ & $\begin{array}{c}3.62 \\
(3.50,3.75)\end{array}$ & $\begin{array}{c}3.36 \\
(3.22,3.50)\end{array}$ & $\begin{array}{c}<0.001 \\
(6.88)\end{array}$ \\
\hline & Balanced & $\begin{array}{c}3.78 \\
(3.59,3.97)\end{array}$ & $\begin{array}{c}3.73 \\
(3.53,3.95)\end{array}$ & $\begin{array}{c}3.61 \\
(3.48,3.75)\end{array}$ & $\begin{array}{c}3.70 \\
(3.55,3.84)\end{array}$ & \\
\hline \multirow[t]{2}{*}{$\mathrm{Ca}^{2+}$} & Saline & $\begin{array}{c}1.93 \\
(1.84,2.02)\end{array}$ & $\begin{array}{c}1.89 \\
(1.83,1.94)\end{array}$ & $\begin{array}{c}1.82 \\
(1.78,1.86)\end{array}$ & $\begin{array}{c}1.79 \\
(1.69,1.89)\end{array}$ & $\begin{array}{l}0.003 \\
(5 \cdot 36)\end{array}$ \\
\hline & Balanced & $\begin{array}{c}1.78 \\
(1.69,1.87)\end{array}$ & $\begin{array}{c}1.87 \\
(1.81,1,93)\end{array}$ & $\begin{array}{c}1.87 \\
(1.83,1.91)\end{array}$ & $\begin{array}{c}1.97 \\
(1.87,2.07)\end{array}$ & \\
\hline \multirow[t]{2}{*}{$\mathrm{Mg}^{2+}$} & Saline & $\begin{array}{c}0.83 \\
(0.78,0.88)\end{array}$ & $\begin{array}{c}0.79 \\
(0.74,0.84)\end{array}$ & $\begin{array}{c}0.78 \\
(0.72,0.82)\end{array}$ & $\begin{array}{c}0.80 \\
(0.71,0.86)\end{array}$ & $\begin{array}{l}<0.001 \\
(10.36)\end{array}$ \\
\hline & Balanced & $\begin{array}{c}0.71 \\
(0.66,0.77)\end{array}$ & $\begin{array}{c}0.77 \\
(0.72,0.82)\end{array}$ & $\begin{array}{c}0.83 \\
(0.78,0.89)\end{array}$ & $\begin{array}{c}0.94 \\
(0.86,1.01)\end{array}$ & \\
\hline
\end{tabular}

Repeated measures ANOVA between group analysis with regard to time was applied. Assumption of normality, homogenicity of variance and compound symmetry were checked and were fulfilled. 
Table 5. Comparison of acid base status between saline vs. balance fluid based on time (time-treatment interaction)

\begin{tabular}{|c|c|c|c|c|c|c|}
\hline Parameter & Type of fluid & $\begin{array}{l}\text { o hours } \\
\text { Mean } \\
(95 \% \mathrm{CI})\end{array}$ & $\begin{array}{c}8 \text { hours } \\
\text { Mean } \\
(95 \% \mathrm{CI})\end{array}$ & $\begin{array}{l}16 \text { hours } \\
\text { Mean } \\
(95 \% \mathrm{CI})\end{array}$ & $\begin{array}{l}24 \text { hours } \\
\text { Mean } \\
(95 \% \mathrm{CI})\end{array}$ & $P$-value (F) \\
\hline \multirow[t]{2}{*}{$\mathrm{pH}$} & Saline & $\begin{array}{c}7.36 \\
(7.35,7.39)\end{array}$ & $\begin{array}{c}7.35 \\
(7.32,7.37)\end{array}$ & $\begin{array}{c}7.38 \\
(7.36,7.41)\end{array}$ & $\begin{array}{c}7 \cdot 37 \\
(7 \cdot 36,7.39)\end{array}$ & $\begin{array}{l}0.572 \\
(0.67)\end{array}$ \\
\hline & Balanced & $\begin{array}{c}7 \cdot 37 \\
(7,35,7 \cdot 39)\end{array}$ & $\begin{array}{c}7.37 \\
(7.34,7.39)\end{array}$ & $\begin{array}{c}7.39 \\
(7.37,7.42)\end{array}$ & $\begin{array}{c}7.40 \\
(7 \cdot 38,7.42)\end{array}$ & \\
\hline \multirow[t]{2}{*}{$\mathrm{pCO}_{2}$} & Saline & $\begin{array}{c}36.11 \\
(34.07 \\
38.15)\end{array}$ & $\begin{array}{c}38.00 \\
(35.99 \\
40.02)\end{array}$ & $\begin{array}{c}34.02 \\
(32.34 \\
35.69)\end{array}$ & $\begin{array}{c}36.68 \\
(35.26 \\
38.08)\end{array}$ & $\begin{array}{l}0.004 \\
(4.89)\end{array}$ \\
\hline & Balanced & $\begin{array}{c}38.69 \\
(36.59 \\
40.80)\end{array}$ & $\begin{array}{c}35.33 \\
(33.25 \\
37.42)\end{array}$ & $\begin{array}{c}36.22 \\
(34.49 \\
37.95)\end{array}$ & $\begin{array}{l}36.62 \\
(35.16, \\
38.08)\end{array}$ & \\
\hline \multirow[t]{2}{*}{ BE- } & Saline & $\begin{array}{c}-4.00 \\
(-5.26,-2.76)\end{array}$ & $\begin{array}{l}-3.85 \\
(-4.96 \\
-2.74)\end{array}$ & $\begin{array}{l}-3.77 \\
(-5.00 \\
-2.53)\end{array}$ & $\begin{array}{c}-3.20 \\
(-4.26,-2.14)\end{array}$ & $\begin{array}{l}0.049 \\
(2.78)\end{array}$ \\
\hline & Balanced & $\begin{array}{l}-2.17 \\
(-3.45, \\
-0.88)\end{array}$ & $\begin{array}{l}-4.15 \\
(-5.30 \\
-3.00)\end{array}$ & $\begin{array}{l}-2.21 \\
(-3.47 \\
-0.95)\end{array}$ & $\begin{array}{c}-1.35 \\
(-2.43,-0.27)\end{array}$ & \\
\hline \multirow[t]{2}{*}{$\mathrm{HCO}_{3^{-}}$} & Saline & $\begin{array}{c}21.08 \\
(20.06 \\
22.11)\end{array}$ & $\begin{array}{l}20.76 \\
(19.62, \\
21.89)\end{array}$ & $\begin{array}{c}21.23 \\
(20.21 \\
22.24)\end{array}$ & $\begin{array}{l}22.03 \\
(21.24 \\
22.82)\end{array}$ & $\begin{array}{l}0.031 \\
(4.65)\end{array}$ \\
\hline & Balanced & $\begin{array}{l}22.83 \\
(21.76, \\
23.88)\end{array}$ & $\begin{array}{l}20.53 \\
(19.35, \\
21.70)\end{array}$ & $\begin{array}{l}22.89 \\
(21.85, \\
23.94)\end{array}$ & $\begin{array}{c}23.48 \\
(22.66 \\
24.28)\end{array}$ & \\
\hline \multirow[t]{2}{*}{ lactate } & Saline & $\begin{array}{c}3.25 \\
(1.49,5.01)\end{array}$ & $\begin{array}{c}1.70 \\
(1.44,1.96)\end{array}$ & $\begin{array}{c}1.78 \\
(1.12,2.45)\end{array}$ & $\begin{array}{c}1.12 \\
(0.99,1.26)\end{array}$ & $\begin{array}{l}0.571 \\
(0.67)\end{array}$ \\
\hline & Balanced & $\begin{array}{c}2.80 \\
(0.98,4.61)\end{array}$ & $\begin{array}{c}1.94 \\
(1.67,2.20)\end{array}$ & $\begin{array}{c}1.49 \\
(0.80,2.18)\end{array}$ & $\begin{array}{c}1.27 \\
(1.13,1.41\end{array}$ & \\
\hline
\end{tabular}

Repeated measures ANOVA between group analysis with regard to time was applied. Assumption of normality, homogenicity of variance and compound symmetry were checked and were fulfilled.

\section{Discussion}

The use of a balanced solution is a new approach in fluid management in intraoperative and intensive care settings. Its electrolyte composition is close to the plasma composition and adapts to physiological needs (14). A balanced solution prevents the risk of iatrogenic derangement in electrolytes and acid-base.

The demographic data were comparable in both group, except for GCS at presentation and GCS before operation in both groups. The GCS of patients plays an important role in determining their outcome (14). However, in the current study, the acid-base and electrolytes were not confounded by the patients' GCS at presentation and GCS before operation. The repeated measures analysis of covariates (ANCOVA) was performed with GCS as the covariate, but no significant difference was observed. Therefore, we can conclude that the electrolyte and acidbase statuses were not confounded by the patients' GCS. The duration of operation is also important in determining the outcome of the patients, as the patients may be exposed to secondary effects, such as bleeding, hypothermia, and electrolyte imbalance (15).

Regarding the sodium level, although both fluids resulted in increased sodium content, no incidence of hypernatremia was encountered. Disma et al. (16) found an increase in postinfusion sodium concentration in both NS and $\mathrm{BF}$ groups, but hypernatremia was not observed in the pediatric population. In summary, no significant different was found between both fluids, and prolonged infusion for over 24 $\mathrm{h}$ was not associated with hypernatremia. 
Hyperchloremia upon rapid or prolonged infusion of NS has been discussed in many studies $(7,17)$. A significant difference was found in the mean chloride and increment of chloride level starting at $8 \mathrm{~h}$ in NS in comparison with $\mathrm{BF}$, and the balanced group showed a downward trend of chloride level. However, both groups of fluids showed hyperchloremia at the end of study period. This condition can be due to the high concentration or load of chloride ion in the $\mathrm{NS}$ and $\mathrm{BF}$ in comparison with the plasma chloride concentration to produce iso-osmolar fluid (14). Nonphysiologic levels of chloride in NS have been linked to the development of hyperchloremic metabolic acidosis (6). Scheingraber et al. (18) found that hyperchloremia could impair end-organ perfusion and interfere with the cellular exchange mechanism. Previous studies found that the infusion of NS would lead to increased time to first urination and that a greater frequency of abdominal discomfort has a negative effect on renal blood flow and the glomerular filtration rate (19). However, other authors claimed that hyperchloremic metabolic acidosis was benign and selflimiting (2, 20). Prolonged infusion of NS led to reduced potassium and calcium levels. Mild hypokalemia was observed after a $24 \mathrm{~h}$ infusion of NS, but a more stable potassium level was seen in BF. This situation is particularly true as NS does not contain potassium ion. Zunini et al. (21) found the presence of hypokalemia in pediatric patients with prolonged NS infusion. However, Hadimioglu et al. (22) found no significant changes in the potassium level in different crystalloid solutions because the amount of solution used was relatively less than those in other studies. Calcium level is expected to decrease upon prolonged infusion of NS because it does not contain $\mathrm{Ca}^{2+}$ ion in the solution. However, improved calcium trends were observed in patients infused with $\mathrm{BF}$, and a significant difference was found in the mean calcium concentration between the two groups in a $24 \mathrm{~h}$ infusion. We found that the infusion of $\mathrm{BF}$ over time could improve the calcium level up to $24 \mathrm{~h}$ and that a longer infusion of BF could correct hypocalcaemia. This condition may be particularly true, as patients with TBI tend to have a more variable electrolyte imbalance, and a longer duration of fluid infusion may be needed to achieve a normal electrolyte level. Moreover, crystalloids may require a longer time to reach a stable plasma concentration as compared with colloids. In the current study, we found a stable magnesium level in NS and a gradual improvement in the serum magnesium level after a $24 \mathrm{~h}$ infusion in BF. However, all the values were within the normal range. This condition could be explained by the movement of intracellular magnesium from the cell and the tight regulation of the serum concentration of magnesium (23). However, a more stable electrolyte parameter was observed in the patients in the balanced solution group, as explained in another study (13).

In our study, we found no significant differences in mean $\mathrm{pH}$ concentration between the two groups over a $24 \mathrm{~h}$ infusion. Similarly, Hadimioglu et al. (22) reported no associated metabolic acidosis aside from hyperchloremia in patients infused with NS during renal transplantation. This finding is contradictory to metabolic acidosis after the rapid infusion of NS, as shown in other studies $(2,18)$. This situation could be attributed to the reduction of $\mathrm{paCO}_{2}$ in compensating for the metabolic acidosis (20). Furthermore, the infusion of NS in this study was given slowly as maintenance fluid compared with other studies, which used the rapid infusion of NS that caused insignificant $\mathrm{pH}$ alteration. However, NS significantly caused a reduction in $\mathrm{BE}$ unlike in the balanced group. A previous study that compared saline-based fluid and $\mathrm{BF}$ in surgical patients demonstrated a similar finding (13). NS showed a more negative value of $\mathrm{BE}$ than $\mathrm{BF}$. This finding is inevitable because NS contains more chloride, which subsequently leads to this condition. According to previous studies, the balanced solution caused significant acid-base stability compared with saline-based solution in elderly surgical patients and healthy volunteers $(11,13)$. A significant difference in bicarbonate level was found between the two groups in a $24 \mathrm{~h}$ period. The mean serum bicarbonate in the balanced solution was higher than that in the saline group but was still in the normal range. Sterofundin, which was used in this study, contains acetate as a buffer in comparison with the LR solution, which uses lactate as a buffer (24). The balanced solution gives a more stable plasma bicarbonate level. A pilot study by Hofmann-Kiefer showed that slight advantages were observed in the acetate-buffered solution in terms of $\mathrm{pH}$ and plasma $\mathrm{HCO}_{3}$ - stability in comparison with the lactate-based balanced solution (25). The balanced solution with acetate buffer is also more advantageous than a lactate-based buffer in terms of metabolism and clearance because it does not depend on the liver function (14). 


\section{Conclusion}

In conclusion, BF therapy showed better effects in maintaining higher electrolyte parameters and reducing the trend toward hyperchloremic metabolic acidosis than NS therapy during prolonged fluid therapy for postoperative TBI patients. Although the infusion of BF showed mild hyperchloremia, it improved the calcium level. Furthermore, BF showed a normal BE level after a $24 \mathrm{~h}$ infusion. Nevertheless, both groups had a normal bicarbonate level after the study was completed.

\section{Acknowledgements}

This study was financially supported by the Short Term Grant of Universiti Sains Malaysia [304.PPSP.61312128].

\section{Authors' Contributions}

Conception and design: MHH, WMNWH, RHMZ Analysis and interpretation of the data: $\mathrm{MHH}$, WMNWH

Drafting of the article: $\mathrm{MHH}$

Critical revision of the article for important intellectual content: MHH, WMNWH, RHMZ, WFWMS, HZA, CSE

Final approval of the article: MHH, WMNWH, RHMZ, WFWMS, HZA, CSE

Provision of study materials or patients: $\mathrm{MHH}$, RHMZ

Statistical expertise: $\mathrm{MHH}, \mathrm{WMNWH}$

Obtaining of funding: MHH, WFWMS, HZA,

CSE

Administrative, technical, or logistic support: MHH, WMNWH, RHMZ, WFWMS, HZA, CSE

Collection and assembly of data: $\mathrm{MHH}$

\section{Correspondence}

Dr Mohamad Hasyizan Hassan

MBBS (Universiti Malaya), MMed (Anesth) USM

Department of Neurosciences, School of Medical

Sciences,

Health Campus, Universiti Sains Malaysia,

16150 Kubang Kerian, Kelantan,

Malaysia.

Tel: 097476301

H/P: 0129829552

E-mail: hasyizan@usm.my

\section{References}

1. Tommasino C, Moore S, Todd MM. Cerebral effects of isovolemic hemodilution with crystalloid or colloid solutions. Critical Care Medicine. 1988;16(9):862-868. https://doi. org/10.1097/00003246-198809000-00009

2. McFarlane C, Lee A. A comparison of Plasmalyte 148 and $0.9 \%$ saline for intra-operative fluid replacement. Anaesthesia. 1994;49(9):779781. https://doi.org/10.1111/j.1365-2044.1994. tbo4450.x

3. Kellum JA. Saline-induced hyperchloremic metabolic acidosis. Critical Care Medicine. 2002;30(1):259-261. https://doi. org/10.1097/00003246-200201000-00046

4. Mythen MG, Hamilton MA. Hyperchloremic metabolic acidosis: is it clinically relevant? Transfus Altern Transfus Med. 2001;3(4):1519. https://doi.org/10.1111/j.1778-428X.2001. tbooo40.x

5. Smith I, Kumar P, Molloy S, Rhodes A, Newman $\mathrm{P}$, Grounds R, et al. Base excess and lactate as prognostic indicators for patients admitted to intensive care. Intensive Care Medicine. 2001;27(1):74-83. https://doi.org/10.1007/ s001340051352

6. Williams EL, Hildebrand KL, McCormick SA, Bedel MJ. The effect of intravenous lactated Ringer's solution versus $0.9 \%$ sodium chloride solution on serum osmolality in human volunteers. Anesthesia \& Analgesia. 1999;88(5):999-1003. https://doi. org/10.1097/00000539-199905000-00006

7. Waters JH, Gottlieb A, Schoenwald P, Popovich MJ, Sprung J, Nelson DR. Normal saline versus lactated Ringer's solution for intraoperative fluid management in patients undergoing abdominal aortic aneurysm repair: an outcome study. Anesthesia \& Analgesia. 2001;93(4):817-822. https://doi.org/10.1097/00000539-20011000000004

8. Boldt J. II. The balanced concept of fluid resuscitation. Br J Anaesth. 2007;99(3):312-315. https://doi.org/10.1093/bja/aem219

9. Boldt J. Volume therapy in cardiac surgery: are Americans different from Europeans? $J$ Cardiothorac Vasc Anesth. 2006;20(1):98-105. https://doi.org/10.1053/j.jvca.2005.07.023 
10. Roche AM, James MF, Bennett-Guerrero E, Mythen MG. A head-to-head comparison of the in vitro coagulation effects of salinebased and balanced electrolyte crystalloid and colloid intravenous fluids. Anesthesia \& Analgesia. 2006;102(4):1274-1279. https://doi. org/10.1213/o1.ane.0000197694.48429.94

11. Wilkes NJ, Woolf RL, Powanda MC, Gan TJ, Machin SJ, Webb A, et al. Hydroxyethyl starch in balanced electrolyte solution (Hextend $囚)$ Pharmacokinetic and pharmacodynamic profiles in healthy volunteers. Anesthesia \& Analgesia. 2002;94(3):538-544. https://doi. org/10.1097/00000539-200203000-00011

12. Martin G, Bennett-Guerrero E, Wakeling $\mathrm{H}$, Mythen M, El-Moalem H, Robertson K, et al. A prospective, randomized comparison of thromboelastographic coagulation profile in patients receiving lactated Ringer's solution, $6 \%$ hetastarch in a balanced-saline vehicle, or $6 \%$ hetastarch in saline during major surgery. $J$ Cardiothorac Vasc Anesth. 2002;16(4):441-446. https://doi.org/10.1053/jcan.2002.125146

13. Wilkes NJ, Woolf R, Mutch M, Mallett SV, Peachey T, Stephens R, et al. The effects of balanced versus saline-based hetastarch and crystalloid solutions on acid-base and electrolyte status and gastric mucosal perfusion in elderly surgical patients. Anesthesia \& Analgesia. 2001;93(4):811-816. https://doi. org/10.1097/00000539-200110000-00003

14. Guidet B, Soni N, Della Rocca G, Kozek S, Vallet $\mathrm{B}$, Annane D, et al. A balanced view of balanced solutions. Crit Care. 2010;14(5):325. https://doi. org/10.1186/cc9230

15. Curry P, Viernes D, Sharma D. Perioperative management of traumatic brain injury. Int $J$ Crit Illn Inj Sci. 2011;1(1):27. https://doi. org/10.4103/2229-5151.79279

16. Disma N, Mameli L, Pistorio A, Davidson A, Barabino P, Locatelli BG, et al. A novel balanced isotonic sodium solution vs normal saline during major surgery in children up to 36 months: a multicenter RCT. Pediatric Anesthesia. 2014;24(9):980-986. https://doi.org/10.1111/ pan.12439

17. Adrogué HJ, Madias NE. Hypernatremia. New England Journal of Medicine. 2000;342(20):1493-1499. https://doi. org/10.1056/NEJM200005183422006
18. Scheingraber S, Rehm M, Sehmisch C, Finsterer U. Rapid saline infusion produces hyperchloremic acidosis in patients undergoing gynecologic surgery. Anesthesiology. 1999;90(5):1265-1270. https://doi.org/10.1097/00000542-19990500000007

19. Wilcox CS. Regulation of renal blood flow by plasma chloride. Journal of Clinical Investigation. 1983;71(3):726. https://doi. org/10.1172/JCI110820

20. Mathes D, Morell R, Rohr M. Dilutional acidosis: is it a real clinical entity? Anesthesiology. 1997;86(2):501-503. https://doi. org/10.1097/00000542-199702000-00028

21. Zunini GS, Rando KA, Cox RG. Fluid replacement in craniofacial pediatric surgery: normal saline or ringer's lactate? $J$ Craniofac Surg. 2011;22(4):1370-1374. https://doi.org/10.1097/ SCS.obo13e31821c94db

22. Hadimioglu N, Saadawy I, Saglam T, Ertug Z, Dinckan A. The effect of different crystalloid solutions on acid-base balance and early kidney function after kidney transplantation. Anesthesia \& Analgesia. 2008;107(1):264-269. https://doi. org/10.1213/ane.obo13e3181732d64

23. Drueke T, Lacour B. Magnesium homeostasis and disorders of magnesium metabolism. Comprehensive clinical nephrology. 3rd ed. Philadelphia: Mosby; 2007:136-138.

24. Morgan T, Venkatesh B. Designing 'balanced' crystalloids. Critical Care and Resuscitation, 2003;12(4):284-291.

25. Hofmann-Kiefer KF, Chappell D, Kammerer T, Jacob M, Paptistella M, Conzen P, et al. Influence of an acetate-and a lactate-based balanced infusion solution on acid base physiology and hemodynamics: an observational pilot study. Eur J Med Res. 2012;17(1):1-8. https://doi. org/10.1186/2047-783X-17-21 